\title{
Accountability and Democracy in the Case of Using Force under International Auspices
}

Charlotte $\mathrm{Ku}$

Texas A\&M University School of Law, cku@law.tamu.edu

Harold K. Jacobson

Follow this and additional works at: https://scholarship.law.tamu.edu/facscholar

Part of the Law Commons

\section{Recommended Citation}

Charlotte Ku \& Harold K. Jacobson, Accountability and Democracy in the Case of Using Force under International Auspices, 94 Am. Soc'y Int'I L. Proc. 19 (2000).

Available at: https://scholarship.law.tamu.edu/facscholar/414

This Article is brought to you for free and open access by Texas A\&M Law Scholarship. It has been accepted for inclusion in Faculty Scholarship by an authorized administrator of Texas A\&M Law Scholarship. For more information, please contact aretteen@law.tamu.edu. 


\title{
ACCOUNTABILITY AND DEMOCRACY IN THE CASE OF USING FORGE UNDER INTERNATIONAL AUSPICES
}

\author{
by Charlotte Ku and Harold K. Jacobson
}

This presentation derives from a large research project that has been more than three veirs in progress and reflects the work of a multinational team of lawyers, policy analysts, and political scientists. The project is supported by the Ford Foundation and will conclude at the end of 2000 with the completion of a book that will cover the experience of nine democracies in deploying their military forces under international auspices as this experience relates to two large questions.

The working table of contents listing the authors and their topics follows:

\section{ACCOUNTABILITY AND USING MILITARY FORCES \\ UNDER THE AUSPICES OF INTERNATIONAL INSTITUTIONS}

I. Using M Silitary Force Under International Auspices and Democratic Accountability Charlotte $\mathrm{Ku}$, American Society of International Law; and Harold $\mathrm{K}$. Jacobson, University of Michigan

II. Changing Trends in Executive and Legislative Powers to Authorize the Use of Force: The Interface of National Constitutional Systems with International Law and Institutions

Lori F. Damrosch, Columbia University School of Law

III. Domestic Political Considerations and Decisions to Commit Troops

Karen Mingst, University of Kentucky

IV. Changing Requirements of Collective Security

Edwin Smith, University of Southern California Law Center

V. The Legal Status of Personnel in Military Operations Under International Auspices: The Question of Criminal Responsibility

Robert C.R. Siekmann, T.M.C. Asser Institute, The Hague

VI. India

Gen. Dipankar Banerjee, Regional Centre of Strategic Studies, Sri Lanka; and Ramesh Thakur, United Nations University, Tokyo

VII. Japan

Akiho Shibata, Okayama University Faculty of Law

VII. Canada

Fen Osler Hampson, Carleton University, Ottawa

IX. Nortray

Knut Nustad and Henrik Thune, Norwegian Institute of International Affairs, Oslo

X. Germany'

Georg Nolte, Institute of International Law, University of Goettingen

XI. France

I'ves Boyer, Fondation pour la Recherche Stratégique, Paris; Serge Sur, University of Paris II; Olivier Fleurence, International Atomic Energy Agency, Vienna

XII. Russian Federation

Bakhtiyar R. Tuzmukhamedov, Moscow State Linguistic University

Kun L vecutis e Dircetor, American Society of International Law.Jacobson is Jesse Siddal Reeves Professor of Politie sl chence and Stuior Research Scientist, University of Michigan, Ann Arbor, MI. 
XIII. United Kingdom

Nigel D. White, University of Nottingham Department of Law

XIV. United States

Michael J. Glennon, University of California at Davis Law School

XV. Conclusion

Charlotte $\mathrm{Ku}$ and Harold $\mathrm{K}$. Jacobson

The project examines two questions:

- What is the interactive relationship between international commitments and national constitutional and political requirements?

- How does this relationship work for democracies, and does it ensure accountability, including democratic accountability for decisions made by international institutions?

The reason for examining these two questions at this time stems from two sets of circumstances evident since the end of the Cold War in 1989:

- In contrast to the final days of World Wars I and II, when much thinking and planning was given to the order and structure of the world to come, there seemed to be little preparation for the end of the Cold War. Leaders met at a glittering summit in Paris in 1990 to proclaim the triumph of democracy, but left with few details on how this was to be maintained.

- There seemed to be an unspoken assumption that the post-World War II security system, whose effective functioning had been stalled by the Cold War, would now be allowed to function. The UN Security Council met at the head-of-government level in January 1992 to consider the role of the postwar system, but events, particularly as related to intrastate conflict, indicate the inadequacy of this assumption.

But why examine democracies and why examine issues of the use of military forces? Democracies, starting with the United States, are world powers that play crucial roles in maintaining international order. Democracies require some measure of popular support for actions taken by their governments. The question for this project is: What level of popular support and what level of accountability are required, and how are these achieved in democracies? These questions are fundamental to assessing the viability of any post-Cold War security system.

The military action by the North Atlantic Treaty Organization (NATO) in Kosovo added an unexpected element to the study after the project got underway, and introduced the international legal ambiguities and national questions of acting without the authorization of the UN Security Council. The Kosovo action demonstrated that the post-Cold War system as a revival of the post-World War II system was not adequate to address the conflicts of the postCold War period, and that the security packages represented by the United Nations and NATO needed to be reconsidered both internationally and nationally to fit the problems of today.

\section{THE SCOPE OF THE STUDY}

Although military forces have been used under the auspices of the Organization of American States, Economic Community of West African States (ECOWAS), the Organization of East Caribbean States and others, we focus on the United Nations and NATO for three reasons:

1. the centrality of the United Nations and the large number of occasions that it has authorized the use of military forces;

2. the fact that NATO maintains a standing military force that has now been deployed in serious military operations; and

3. the fact that NATO's member states are all democracies.

Our study explores the historical experience in nine countries concerning the use of military forces under international auspices: Canada, France, Germany, India, Japan, Norway, 
the Russian Federation, the United Kingdom, and the United States. These countries are all democracies, and all have contributed military forces to a variety of military operations conducted under UN auspices; the six that are members of NATO have contributed forces to its military operations. Four (France, Russia, the United Kingdom, and the United States) are permanent members of the UN Security Council, and three (Germany, India, and Japan) aspire to be permanent members of the Security Council. Two (Canada and Norway) are among the states that have traditionally been committed to and provided substantial support for international causes. These nine countries furthermore have a crucial military capability.

Our study explores the experiences of these countries in order to clarify what processes on the domestic level have developed to accompany the evolution of the uses of force on the international level. We explore how the international community has moved toward using military forces under the auspices of international institutions for collective purposes while at the same time maintaining accountability in democracies at national and individual levels.

We focus on the internal situation only because of its importance in assuring the effectiveness of international decisions, although we acknowledge that questions of democratic process also apply to international institutions and decision-making processes. We are interested in the nexus of the international and the domestic because we believe that unless this is understood and provided for, the project of placing limits on the unilateral use of force and establishing mechanisms so that force can be used under the auspices of international Institutions for collective purposes will be severely constrained.

\section{CONTROLLING THE USES OF FORCE}

The historic evolution in control over the use of force-creating the monopoly of coercion-was a crucial feature of the creation of modern nation-states. For democracies, ensuring that there would be accountability for the use of military forces was a central component of the struggle to establish democratic forms of government in these states. At the same time, states have struggled to balance the democratic requirements of debate, consensus building, and consent with the exigencies of national defense. National defense is the chief concern of most states where military forces are concerned, and within limits broad discretion 1) allowed the executive in order to respond to security crises. Can the same system of accountability apply when military forces are used under the auspices of international institutions? Have domestic norms, including those of democratic accountability, evolved to support the international institutions and decisions that are now in operation? Are questions of accountability different if force is used under national or international auspices, or are the issues essentially the same?

Generalizing from the experience of the United Nations and NATO since World War II, the use of military forces under international auspices can be placed in five broad categories that can be described by their general purposes. ${ }^{1}$ These have in common collective action and include variations on the ideal of collective security in the more robust forms of action. Each derives either explicitly or implicitly from some form of legal mandate through decisions of bodies like the UN Security Council authorized by states to make such decisions.

Although now widely accepted as legally permitted practices, as variants of collective security, their legal bases were not without controversy when first introduced and were scrutinized by scholars and commentators in their early history. ${ }^{2}$ The categories are based on the number of military personnel involved, their mandate and their rules of engagement, and

Thu cutegorization draws heavily on the concepts developed in GARETH EvaNS, COOPERATING FOR PEACE: THE GLOB \L AGENDA FOR THE 1990S AND BEXOND (1993). It is related to but different from the categorization developed by' Boutros Bourros-GHaLI, AN AGENDA FOR PEACE (1992). Of course, it draws more broadly on the u rde literature concernme peacekeeping, including PAUL F. DIEHL, INTERNATIONAL PEACEKEEPING (1993); UN PE ACEKELPING, AIIERIC AN POLICY, AND THE UNCINIL WARS OF THE 1990S (William J. Durch ed.), (1996); A CRISIS IN EXRECT ITIONS: UN PE ACEKEEPING IN THE 1990 S (Ramesh Thakur \& Carlyle A. Thayer eds.), (1995); and JAMES S SUTTERLIV. THE UNTED NATIONS AND THE MLALVTENANCE OF INTERNATIONAL SECURITY: A CHALLENGE TOBEMET (1995).

Sec Oscar Schachter, International LAw in ThEORY AND PRACTICE 389-417 (1991). 
whether or not they enter the territory of the state where they operate with the consent of that state. The five categories are:

1. Monitoring and observation. Eighteen of the deployments of military force under the auspices of the United Nations have been for the purpose of monitoring and observation. Eleven of these missions were started before 1990 (starting with the United Nations Truce Supervision Organization in 1949) and seven after 1990. Monitoring and observation missions constituted almost 60 percent of the United Nations' deployments before 1990, but less than 20 percent of the deployments after 1990.

2. Traditional peacekeeping. In all, there have only been four traditional peacekeeping forces: United Nations Emergency Force I (UNEF I), the United Nations Force in Cyprus (UNFCYP), UNEF II, and the United Nations Force in Lebanon (UNIFIL). All of these forces were originally deployed prior to 1990 .

3. Peacekeeping plus state building. The exemplar case of peacekeeping plus state building is the United Nations Transitional Authority in Cambodia (UNTAC). UNTAC was authorized in 1992 and involved more than 20,000 personnel. There have been twenty-five cases of peacekeeping plus state building, and all but two of these were deployed after 1990.

4. Force to ensure compliance with international mandates. Established in 1960, the United Nations Operation in the Congo (UNOC, or ONUC, for Organisation des Nations Unies au Congo) provided the first instance in which military forces deployed under UN auspices used force to ensure compliance with an international mandate. All of the forces deployed by the United Nations and NATO in the former Yugoslavia would be in this category. Four of the fifty-four military forces deployed under UN auspices fall in this category, as do all four of those deployed by NATO. NATO's International Force (IFOR) was the largest of these military operations. It included more than 60,000 personnel. Of the deployments of force in this category, only ONUC occurred before 1990.

5. Enforcement. The UN-sponsored operations in Korea and Kuwait are the two cases of enforcement action. The Korean operation involved close to a million personnel, and the Kuwait operation almost 800,000. UN forces suffered 95,000 fatalities in the Korean War, but only 240 in the Gulf War.

The categorization of the fifty-eight instances in which military force has been used under the auspices of the United Nations and NATO is summarized in Table 1 below.

Table 1: Uses of Forces Under the Auspices of the United Nations and NATO

Forms of use of force

Period

1946-1989 1990-1999

\begin{tabular}{|c|c|c|}
\hline \multirow[b]{2}{*}{$\begin{array}{l}\text { Monitoring and } \\
\text { observation }\end{array}$} & \multirow[b]{2}{*}{$11(57.9 \%)$} & \multirow[b]{2}{*}{$7(17.9 \%)$} \\
\hline & & \\
\hline Traditional peacekeeping & $4(21.0 \%)$ & 0 \\
\hline $\begin{array}{l}\text { Peacekeeping plus state } \\
\text { building }\end{array}$ & $2(10.5 \%)$ & $23(59.0 \%)$ \\
\hline $\begin{array}{l}\text { Force to ensure } \\
\text { compliance }\end{array}$ & $1(5.3 \%)$ & $8(20.5 \%)$ \\
\hline Enforcement & $1(5.3 \%)$ & $1(2.6 \%)$ \\
\hline Total & $19(100 \%)$ & $39(100 \%)$ \\
\hline
\end{tabular}

In Table 1, the uses of military forces are classified according to their ultimate purpose. In some cases, missions started off modestly and subsequently were expanded. Table 1 divides 
the instances in which military forces were deployed into two periods, during the Cold War and after the Cold War.

Table 1 shows clearly that military forces were used under international auspices by the United Nations and NATO much more frequently in the decade starting in 1990 than they were used in the preceding four decades. They were used nineteen times between 1945 and 1989, but they were used thirty-nine times between 1990 and 1999. The table also shows clearly that the forms of the use of force were quite different in the two periods. Monitoring and observation missions constituted almost 60 percent of the deployments of military force in the first perrod, while in the second period they constituted less than 20 percent of the deployments.

In sharp contrast to the missions deployed only with the consent of the host state, many of the uses of force in the 1990 s were deployed without the consent of the host state, and consequently were more intrusive in its affairs. They were also used much more frequently in intrastate conflicts. Roughly one out of five deployments in the earlier period was in an intrastate dispute; almost nine out of ten deployments in the latter period were in intrastate disputes. The increasing involvement of military forces acting under the auspices of international institutions in intrastate conflicts reflects a broad development in international affairs.

Of the fifty-eight deployments, sixteen (27.6 percent) were in Europe, fourteen (24.1 percent $)$ in Sub-Saharan Africa, thirteen (22.4 percent) in North Africa and the Middle East, seven ( 2.1 percent) in the Americas, five (8.6 percent) in East Asia and the Pacific, and three (5.2 percent) in South Asia. For operations conducted under the auspices of the United Nations other than the Korean War, the mean number of fatalities resulting from military actions by the forces was less than thirty-eight; the mean cost of a deployment was $\$ 210,000,000$.

\section{IDENTIFYING AREAS OF ACCOUNTABILITY}

History and experience regarding the use of force under international auspices have produced questions concerning forms for authorization, national responsibility, and individual responsibility for the conduct of operations in the field. As the forms of the use of force have multiplied, so have the questions of authority and responsibility in deciding to deploy troops, to select military and political objectives, and to incur risk. These raise issues of linking the requirements of domestic accountability in democracies to decisions and actions taken internationally and collectively.

Five forms of authorization and responsibility can be identified, each of which raises its own set of accountability issues:

1. international authorization to deploy military forces;

2. national authorization to deploy military forces;

3. civilian/political control of military personnel and operations;

4. civilians' responsibility to the military for their safety; and

5. responsibility to comply with norms governing the conduct of soldiers and other international personnel in the field.

Democratic governments over time have developed internal procedures that cover the last four of these issues. These procedures are embedded in constitutions and political and military traditions. A considerable body of moral doctrine that can be used to guide choices with respect to these issues has also been developed. The just war doctrine is a notable example. The first issue is newer and arises as a consequence of the effort to shift the legitimate use of force from nation-states to international institutions and from interstate to intrastate conflict. While there are bodies of doctrine with respect to the last four issues, it is not clear how these should be applied when forces are being used under the auspices of an international institution. Some of the implications with respect to each of the issues are discussed below. 
Table 2 combines the categories relating to the forms of use of force and the forms of authorization and responsibility. This matrix provides an organizing framework for understanding where and how international and national systems interact. It is based on the assumption that different uses of military force will raise issues of accountability in different ways. The basic hypothesis is that the greater the risk to soldiers' lives, the longer the duration of the operation, and the less certain the outcome of an operation, the greater the demand will be for review by domestic institutions to enforce accountability. This is not to say, however, that we consider democracies incapable of long engagements. It is just that long engagements may require different internal processes and points of accountability from those required for short ones.

Table 2: Uses of Military Forces and Forms of Authorization and Responsibility

Forms of authorization and responsibility

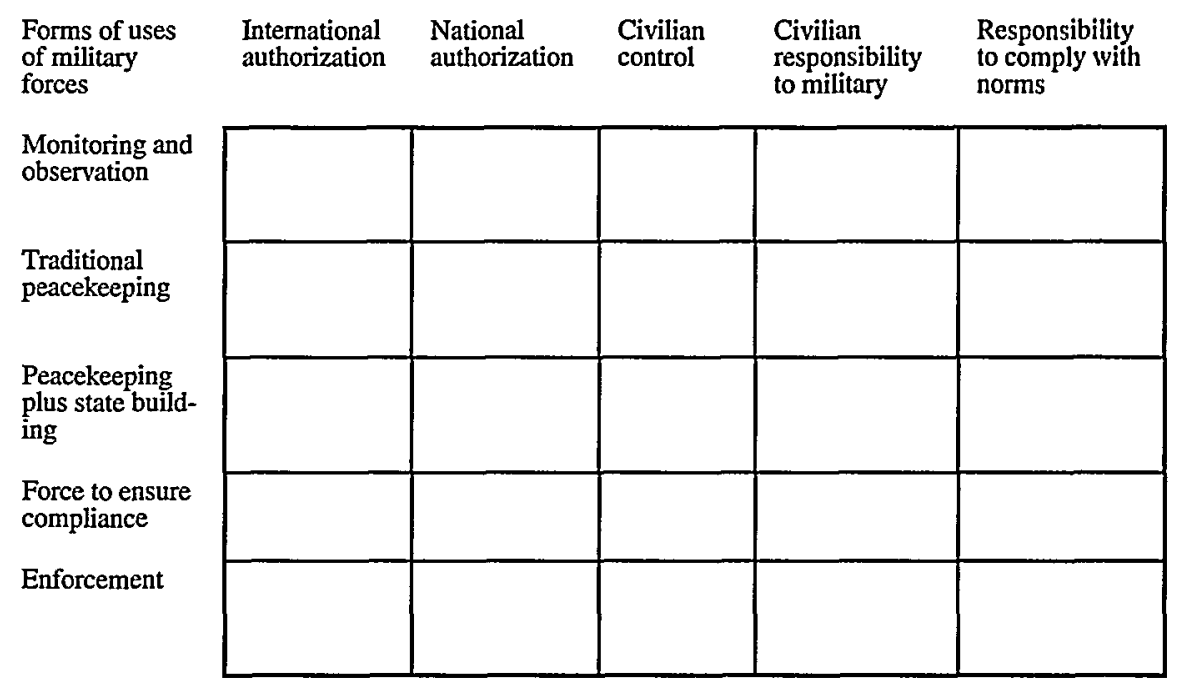

INTERNATIONAL AUTHORIZATION TO DEPLOY MILITARY FORCES

The accountability here is to provide a mandate to use military forces in accordance with international law and practice. It is further to provide the basis for a viable operation using national resources. Much collective action has been taken that for the most part is accepted international practice raising few questions of accountability. So of five forms of force, the major focus is on the two most robust-force to ensure compliance with international mandates and enforcement.

In these cases, a particularly relevant question is how international decisions can provide for the relevant requirements of accountability in the uses of military forces by particular democracies. The Security Council was set up to put decision making in the hands of those with the greatest capacity, but is this basis for decision making adequate to address situations of humanitarian crisis where the objective tests and bases for international action may be open to question? Does it matter if the decision makers are those who will have principal roles in carrying out the decisions?

The United States and the United Kingdom have been the leading proponents of the view that when the Security Council cannot act because of the veto, decisions of the UN General Assembly or the NATO Council constitute appropriate authorization for the deployment of military forces. The United States and the United Kingdom were cosponsors of the Uniting for Peace Resolution in 1950, which allowed the General Assembly to act in crisis situations when the Security Council could not act because of the inability of the permanent members to agree. 
Even their Western allies have opposed this view on occasion, and China and the Soviet Union and later the Russian Federation have consistently opposed it, as have a number of developing countries, including India.

France, Germany, and Italy initially maintained that explicit authorization by the UN Security Council would be required for the NATO Council to authorize any out-of-area military operation. Russia, China, and many other countries, including India, have consistently maintained this position. Britain, in contrast to its allies, felt that international humanitarian law provided an adequate legal basis. The United States assumed adequate authority from Resolution 1199 in which the Security Council acting under Chapter VII of the UN Charter demanded that all parties in Kosovo "cease hostilities." NATO countries eventually were able to build the required consensus to take a decision, but the legitimacy of this decision was contested by states that were not members of NATO.

The broad issues of whether any institution other than the UN Security Council can authorize the deployment of military forces and what constitutes legitimate grounds for intervention within a state are far from resolved. ${ }^{3}$ Further unresolved are the possibilities of these international bodies acting ultra vires, particularly in new areas for collective action. In these cases, will procedures and requirements at the domestic level provide some check on the possible unregulated use of force? Will disquiet over the smaller number of decision makers within bodies like the UN Security Council create problems of accountability for those states excluded from such decision-making bodies?

\section{NATIONAL AUTHORIZATION TO DEPLOY MIITARY FORCES}

What events or processes need to be set into motion for countries to take part in military operations under international auspices? Is there any difference in authorization whether an operation is under international auspices or under a bilateral or other mandate? Does accountability have to be provided through formal constitutional structures to meet the needs of democracy, or can informal means fill this need?

Among the nine countries in our study, six have parliamentary systems-variants of the British Westminster system. France, Russia, and the United States have presidential systems. Yet, in all nine, there is heavy reliance on the executive to carry out the war power, and considerable discretion is allowed the executive. Even in Japan, where separate legislative action is required for the deployment overseas of the Japanese military, the Japanese Diet has little formal means to intervene in the management of foreign affairs by the Cabinet functioning as an executive.

Although the opportunity to pose challenges is available through the budget power and question hour in the parliamentary systems, and through the inquiry power of legislatures in the presidential systems, legislatures in all nine countries nevertheless are reluctant to question the wisdom of an executive decision once troops are deployed, unless a problem arises as occurred for the Americans and Canadians in Somalia, the Dutch in Srebrenica, and the French in Yugoslavia. Legislative involvement in decisions to take part in operations, however, varies. In Germany, Japan, and Russia specific legislative authorization for participation in military operations is required; in the United States, Congress needs to be fully informed of actions taken, and specific time limits are placed on what the president can do on his own.

There seems to be broad reliance on the national and international media in all countries under study to ensure accountability to the general public. The criterion of transparency or acces to information is one of the criteria considered important to fostering and sustaining democracy. At the same time, since public opinion can shift quickly, this may effectively provide the executive wide latitude in pursuing policies regardless of specific legislative

'Sec the debate in ForeIgN AFFAIRS: Michael J. Glennon, The New Interventionism, Foreign AFF., May-June 1949, at 2; Thomas M. Franck et. al., Sidelined in Kosovo? The United Nations' Demise Has Been Exaggerated, FOREIGN AFF., June-July 1999, at 116. 
involvement. Exceptions occur in the cases of the most complex and risky deployments, such as the Operation Allied Force in Kosovo.

In all of the countries in this study, there have been parliamentary discussions about the use of force under the auspices of international institutions. Often these discussions have ended with a resolution taking note of what the government was doing or planned to do. Such resolutions carry the implicit threat that in some future instance the legislature could take a negative decision.

Party politics are also in evidence as a factor in the accountability of decisions to take part in military operations under international auspices. This perhaps is clearest in the case of Germany as it struggled to clarify the framework within which German forces could be sent outside the country. For historical reasons, the very existence of a German armed force was the subject of deep political debate. The need to have a force under the NATO umbrella to face possible attack from the Soviet Union answered that initial question.

However, how to provide for the deployment of German forces outside Germany was another question. In a landmark decision, the German constitutional court decided in 1994 that such deployments would be permissible as long as specific "constitutive approval" was granted by the Bundestag for each deployment. This formula enabled the political parties to accept the overall concept of deployment of German forces outside Germany by assuring the parties that they would always have a voice in the decision to deploy.

Another emerging voice in public opinion in the foreign affairs area is being raised by the nongovernmental organizations (NGOs), whose vociferous and concentrated advocacy can be influential in conditioning public opinion to support military involvement overseas. NGO influence differs from country to country. French NGOs have been especially vocal about decisions for involvement while German and U.S. NGOs have principally functioned in contractor roles involved in rebuilding and humanitarian assistance after a conflict.

Preliminary review of the country studies therefore suggests that democratic accountability is exercised, but often in soft or informal ways rather than the more formal constitutional means that are, nevertheless, available in all cases. As indicated above, informal forms include political culture, contending political parties, leadership, social values, media, financial constraints, and public opinion. ${ }^{4}$ Not only is public support necessary to sustain participation in military operations; it can also can be a key to decisions to become involved, as has been demonstrated in the cases of Japan and Germany.

Is the emerging trend Lori Damrosch describes of more involvement by legislatures the only form of democratic accountability available? In his study for our project of the Canadian experience, Fen Hampson suggests forms of "operational accountability" in which accountability is ensured through finance and the management of operations once decisions are made to take part. Karen Mingst, in her overview chapter on the politics of committing military forces under the auspices of international institutions, concludes that accountability in democracies is more than "legal accountability," and includes the indirect accountability of political culture or the more direct accountability exercised by political or social actors within countries.

\section{CIVILIAN CONTROL, CIVILIAN RESPONSIBILITY, MILITARY RESPONSIBILITY}

\section{Civilian Control of the Military}

How do national command structures work to provide communication between the national civilian and military leaderships and their international counterparts? What about target selection and international mandates for militarily dangerous missions?

What happens if there is a disagreement with the decision made by a non-national commander? See, for example, the Clark/Jackson controversy over the taking of Pristina airport in June 1999. On this last point, civilian control prevailed even at the expense of overruling the

${ }^{4}$ See Karen Mingst, Domestic Political Considerations and the Decision to Use Force under International Auspices (Sept. 1999) (unpublished paper prepared for the ASIL Project on Accountability and the Use of Force under International Auspices). 
senior commander of the operation. The British general, Michael Jackson, refused to obey an order by the American general, Wesley Clark, to secure the airport. Jackson consulted the British government, which supported his refusal to obey the order, and the U.S. Government refused to support Clark.

Although there has been less public discussion about issues of civilian control, it is a factor identified as important to maintaining democracy. ${ }^{5}$ In both UN and NATO operations involving military forces, lines of command have been established that ultimately involve military communders reporting to civilian authorities, usually the UN Secretary-General and Security Council and the NATO Secretary-General and Council. These officials are in turn accountable to the civilian authorities of member states-many of whom themselves would be subject to accountability through the ballot box. The Kuwait operation was an exception in that a UN chain of command was not established-the military forces involved operated under a broad authoration given by the Security Council, but reported to their own civilian authorities.

The NATO operation against Serbia's actions in Kosovo, Operation Allied Force, demonstrated the NATO Council's determination to maintain civilian control. Targets in the air war were chosen by consensus among the civilian authorities of the allies. A plan to interdict oil bound for Yugoslavia that the Supreme Allied Commander of NATO had advocated was put on hold because of allied concerns about its legality. ${ }^{6}$

\section{Cirilian/Military Relations}

Thus issue emanates from an assumption that civilian control accounts for responsible consideration for the use and safety of the military. What happens if forces are perceived to be in danger and more force is needed to ensure their safety? Political leaders who use military force irresponsibly will suffer electoral punishment. The role of the military in decision making may be a key to understanding the feasibility of a mission.

India"s military appears very involved in such decisions, in part because of its size and the related recognition of its political power. India, moreover, seems to have a tolerance for casualter and has probably sustained the largest number of casualties of any country in peacekeeping operations. Japan, conversely, provides little opportunity for military involvement in the decision making about Japanese participation in military operations. The Japanese media furthermore are zealous about monitoring and reporting Japanese participation in oversea operations. For Canada, one of the recommendations made in 1997 by the Commission of Inquiry to investigate charges of misconduct by Canadian soldiers in Somalia wats to involve the military more fully in planning for any deployment of Canadian soldiers.

\section{Responsibility to Comply with International Norms}

This section addresses the individual responsibility for conduct in the field and the emerging international framework for discharging this responsibility through defined norms. One such step was the UN Secretary-General's memo declaring that from 1999, military forces operating under UN commands would be bound by international humanitarian law. ${ }^{7} \mathrm{~A}$ further step cun be seen in the new legal and personal accountability provided through the proposed international criminal court.

National institutions have also been important in ensuring that military personnel comport themselves in accordance with established norms with regard to military conduct. There were major national inquiries into the conduct of the Dutch military forces in Srebrenica and the Canadian military forces in Somalia. Canadian military personnel were prosecuted under Canadian military law. Little exists now, however, beyond these national controls, although

ROBERT A. DAHL, ON DEMOCRACY 147 (1998).

"Se' Frederic L. Kirgis, NATO Interdiction of Oil Tankers Bound for Yugoslavia, ASIL INSIGHT (Apr. 1999), whanushle from <http:/wwwasil.org/insigh33.htm>; Phillippe Sands, Oil Blockage Threatens International Law of the Sect, ASIL INSIGHT (Apr. 1999), obtainable from <http:/www.asil.org/insigh34.htm>.

UN/ST/SGB/1999/13. 
the International Criminal Tribunal for the Former Yugoslavia functions in the territory of the former Yugoslavia and has undertaken a review of NATO actions in that territory.

\section{THE ROLE OF INTERNAL DEMOCRACY IN SHAPING THE POST COLD WAR SECURTTY SYSTEM}

Accountability and democracy are broad terms that apply both to international and national actions and decision making. Democracy is a term that is used to describe both a set of ideals and historical and contemporary political systems. As a concept, democracy means "government by the people." Elaborating on this basic notion, Robert A. Dahl, one of the foremost contemporary democratic theorists, stated that "a key characteristic of democracy is the continuing responsiveness of the government to the preferences of its citizens, considered as political equals."8

Although international decision-making processes are subject to standards of democracy and accountability, they fall far short of meeting the criteria that are normally employed to gauge these concepts. The emerging exception is in the European Union and possible criminal responsibility as carried out by the mandates of either an ad hoc or permanent international criminal tribunal or court. UN decisions to authorize the use of military forces beyond national defense cannot be seen as meeting democratic criteria, but are important as a source of legitimacy both internationally and for many democracies.

As can be seen from the account above, democratic accountability when military forces are used under the auspices of international institutions has primarily been the responsibility of national governments. National governments have responded in various ways. The United States has been at one end of a continuum based on the extent to which the legislature is involved, and India has been at the other. Their respective national constitutions established procedures and traditions that have shaped the response of states. Only five of the nine states-France, India, Russia, the United Kingdom, and the United States-included in our study have used force unilaterally in the period since the end of World War II. For better or worse, the means they employed to ensure democratic accountability when they used force under the auspices of international institutions did not differ significantly from the means they used when they employed force unilaterally.

Dahl has identified five criteria that a process for governing an association should meet to be regarded as democratic ${ }^{9}$ :

Effective participation. Before a policy is adopted by the association, all the members must have equal and effective opportunities for making their views known to the other members as to what the policy should be.

Voting equality. When the moment arrives at which the decision about policy will finally be made, every member must have an equal and effective opportunity to vote, and all votes must be counted as equal.

Enlightened understanding. Within reasonable limits as to time, each member must have equal and effective opportunities for learning about the relevant alternative policies and their likely consequences.

Control of the agenda. The members must have the exclusive opportunity to decide how and, if they choose, what matters are to be placed on the agenda. Thus, the democratic process required by the three preceding criteria is never closed. The policies of the association are always open to change by the members, if they so choose.

Inclusion of adults. All, or at any rate most, adult permanent residents should have the full rights of citizens that are implied by the first four criteria. Before the twentieth century, this criterion was unacceptable to most advocates of democracy.

These five criteria include those that most democratic theorists consider essential. Using more popular language, democratic theorists would speak of freedom of association, assembly, and

${ }^{8}$ ROBERT A. DAHL, POLYARCHY: PARTICTPATION AND OPPOSITION 1 (1971).

${ }^{9}$ DAHL, supra note 5 , at 37,38 . 
participation. They would speak of equality and majority rule. They would discuss forms of representation and voting rules.

Although decision making on matters related to the use of force in the countries represented in our study differs substantially among the countries, in each case it meets these criteria. The criteria are fulfilled by combinations of the formal and informal forms of accountability described above, including the media and public opinion.

\section{NORMIATIVE SIGNIFICANCE AND CAPACITY}

Democracy addresses the processes by which laws are made. The interaction between bodies of law-international and national-is also a consideration of our study. Lori Damrosch's work notes that the first steps toward limiting the use of force were taken in national constitutions:

Milestones along this path begin with the French Constitution of 1791-the first national constitution to renounce wars of conquest-and include the renunciation of war in the post-World War II constitutions of Germany and Japan, as well as other countries. Such constitutional provisions have helped to consolidate the norm of general international law against use of force embodied since 1945 in Article 2, paragraph 4 of the United Nations Charter. National constitutional law in various countries likewise manifests the commitment of those societies to carry out commitments to collective security made within the framework of international organizations.

That the conflicts of today stem from intrastate rather than interstate violence is an important difference, and tests a key assumption of international law-that states are sovereign within their own territory. However, if the international law prohibiting genocide and providing for human rights protection appears to overcome, or even requires overcoming, the concerns of intervention in the internal affairs of states, new standards and procedures must be developed if international relations are not to revert to the unregulated, unilateral, great-power interventions of the nineteenth century. For countries whose constitutions accept international law as part of national law, what changes to international law will be required to make national action possible? In practice for these countries, is there a difference if the law stems from the UN Charter or the North Atlantic Treaty? Will internal legislative controls help to modulate the collective response?

Several actions taken in response to the Operation Allied Force in Kosovo indicate major issues that remain unsettled for the future order for the use of military forces under international institutions. The United Kingdom carefully argued that a right of intervention for humanitarian purposes did not imply a duty to intervene. Norway could find no law to cover its participation in the Operation Allied Force in Kosovo, but agreed to contribute forces on the basis that this was a humanitarian operation. The Canadian government took the position that there was no need for parliamentary debate in Canada until ground troops were introduced because there was no "real war" until ground forces were involved. Each of these interpretations and justifications for participation in the Operation Allied Force left the participating governments uneasy and in search of a more orderly way to respond to future humanitarian crises. The NATO operation also made clear the disapproval of countries like India of the undertaking in the absence of specific appropriate Security Council authorization.

Many countries' concerns ultimately stem from a worry that powerful states will abuse their power at the expense of the less powerful. Yet, maintaining peace and security requires power and effective power. This can be a particularly difficult task to undertake within a multilateral framework when one power prevails over all others. Historical, political, and structural factors further seem "to make even a benign hegemony appear to others as an insufferable bully: the U.S. constitutional bias whereby domestic legislation takes precedence over international commitments and whereby U.S. legislation can be applied extraterritorially." "Several habits have taken root in the course of the twentieth century, however, that

\footnotetext{
"Francois Heisbourg, Ancrican Hegemony? Perceptions of the US Abroad, SuRvival, Winter 1999-2000, at 9.
} 
make a difference and may prevent a return to previous practices. One is the habit of consultation and seeking multilateral support and participation. Increasingly, even the most powerful states appear hesitant to use military forces without some form of international authorization, authorization that at a minimum involves some multilateral consensus. This protracted consensus building may not provide for speedy response, but provides for time to consider a measured response in cases other than the clear ones of invasion across borders. It provides for appropriate parliamentary consultation where necessary. It also provides a measure of protection against abuse by a single powerful military power. ${ }^{11}$

Until clear systems for determining the legitimate grounds for intervention and procedures for taking decisions about this are set up, the problem will remain one of "ad hoc opportunism" by strong military powers. ${ }^{12}$ International law is essential because it shapes the question of whether force can and should be used by making clear what present law permits. How the answers involving international law and its application will be tailored will inevitably grow out of experience and the political process-international and national. This project looks within national systems for some preliminary answers.

The system for authorizing the use of military forces under the auspices of international institutions and then for supervising these forces when they are deployed is a far cry from the vision of centralized control that Woodrow Wilson and others had in mind when they first argued for the creation of a system of collective security. It is also much less centralized than the concept that was embedded in the UN Charter. In actuality, it is a mixed system that involves responsibility and decisions at both the international and the national levels.

Because of this, some might fear that it is both less effective at responding to violations of the UN Charter and less accountable to individuals than it should be. On the one hand, the insistence of national authorities that they be the ones who authorize the use of their military forces in collective actions vitiates any notion that international institutions would automatically deploy military forces any time that international law was violated. On the other hand, the mixture of international and national decision making blurs elements of democratic accountability.

One response to this critique is that however desirable a centralized system might be, the present system is the one that states have been willing to accept. A stronger response is that under present conditions, a centralized system could not meet the criteria of democratic accountability. In addition, however imperfect the present system is, it has worked. Military forces have been deployed fifty-eight times, two of these involved enforcement actions and nine the use of force to ensure compliance with international mandates.

The present system can and should be improved. This should not obscure, however, the significance of the progress that has been made. The project to prohibit the unilateral use of military forces and to establish mechanisms for using military forces collectively has made substantial progress since it was first undertaken at Versailles.

\footnotetext{
"See, for example, the conclusion of Leonard Meeker, former Legal Adviser of the U.S. Department of Statc, that "[w]hile the assertion of an international-law right to intervene to stop genocide would not have the backing of a competent United Nations body, it would signify, being made by NATO, that the air war was not being prosecuted on the decision of the United States alone, but with the concurrence of all nineteen members of NATO. This would give the claim some multilateral character, however incomplete." Unpublished remarks, LAWS group (Apr. 29, 1999), Washington, D.C. 74 (1995)

${ }^{12}$ Michael J. Glennon, Sovereignty and Community after Haiti: Rethinking the Collective Use of Force, 89 AJIL
} 